\title{
Multi-criteria Policy Model in the Development of Cayenne Chili Commodities in Ponorogo Regency
}

\author{
Agustin Rani Nurfadila ${ }^{1, *}$, Ridwan Iskandar ${ }^{2}$, Muksin Muksin $^{3}$ \\ 1, 2, 3 Politeknik Negeri Jember, Indonesia \\ *Corresponding author, Email: agustinrani14@gmail.com
}

\begin{abstract}
Cayenne chili is one of the horticultural crops that has an important role in increasing Indonesian state income. Several factors affect the harvested area of cayenne chili to be volatile so it affects farmers in the cayenne chili commodity business. This study aims to design a strategy for developing cayenne chili agribusiness in Ponorogo Regency. The Multi-criteria Policy method is use to determine the development strategy using scenarios, policies, criteria and actions. The results of the analysis show that the strategy for developing cayenne chili agribusiness in Ponorogo Regency can be developed by looking at the policy paths on the demand side / needs of farmers, namely 1) Development of product promotion, 2) Development of agricultural protection, and 3) Agricultural agribusiness development. While the supply side/government programs are 1) Development of plant protection, 2) Development of food crops and organic horticulture, and 3) Development of hatcheries/nursery.
\end{abstract}

Keywords: Cayenne chili, Multi-criteria policy, Ponorogo Regency

\section{INTRODUCTION}

The agricultural sector is one sector that has an important role in Indonesia's economic development. National Gross Domestic Product (GDP) in the agricultural sector provides a relatively high contribution to Indonesia's economic growth. The contribution of the agricultural sector to the National Gross Domestic Product (GDP) is $15.46 \%$ which is in third place after the industrial and other sectors [1]. However, it cannot be denied that agricultural actors, especially farmers, are still not prosperous [2]. Horticulture is one of the agricultural sub-sectors that plays an important role in supporting the national economy, especially in increasing people's income [3].

Cayenne chili is one of the horticultural crops which is one of the important commodities in Ponorogo Regency which provides the largest contribution in increasing the Gross Regional Domestic Product (GRDP) of Ponorogo Regency. Based on the harvested area of cayenne chili in 2017-2019, Ponorogo Regency is in first place [4]. There are several causes of the harvest being fluctuating, namely the harvest and planting seasons that are not simultaneous, humidity and rainfall in several areas/areas that affect the production of cayenne chili. As a result, cayenne chili becomes scarce and the price fluctuates, so that some farmers do not have the desire to grow cayenne chili. These conditions are the impact of a development strategy that is less directed so that it will have a negative impact on the sustainability of cayenne chili cultivation in Ponorogo Regency, so efforts are needed to improve strategies in developing cayenne chili commodity cultivation. If uncontrolled, the pressure on sustainable farming can contribute negatively to the agricultural sector at large [5]. Efforts that need to be made are using the Multi-criteria Policy analysis tool. The purpose is formulate policies that can use in efforts to develop cayenne chili commodities in Ponorogo Regency.

\section{RESEARCH METHODS}

This study was conducted to analyze the quantitative data obtained by describing and developing a strategy for cayenne chili in Ponorogo Regency. This research is classified as quantitative and qualitative descriptive research. This research was conducted in Slahung District (Simo Village and Gundik Village) and Bungkal 
District (Ketonggo Village and Bedikulon Village) Ponorogo Regency, East Java.

This study used aexpert system technique, is by giving questionnaires to expert respondents. Interested in identifying the strategy for developing cayenne chili in Ponroogo Regency, 2 expert respondents were selected, namely extension workers in Slahung and Bungkal Subdistricts, and 1 Head of Horticulture Division of the Agriculture and Food Service of Ponorogo Regency. Some of the techniques used to obtain data are interviews, questionnaires and documentation. The types of data used in this study are primary and secondary data.

The data obtained were processed and analyzed using the Multi-criteria Policy (Multipol). Multi-criteria Policy is a discrete multi-criteria evaluation method, which is able to handle qualitative information [6]. Multipol is used to develop a policy hierarchy on the development of cayenne chili in Ponorogo Regency. The basis for entering the evaluation method of the Multi-criteria Policy consists of:

a. Evaluation criteria, defined as measurable aspects of the assessment by which the dimensions of the various possible options considered can be characterized.

b. Scenario, defined as a structured future development, in which the goals and objectives set for the system/problem at hand can be achieved.

c. Policy, as a strategy for achieving goals and objectives in a particular planning exercise, is closely related to the political, social, economic and physical context, in which evaluation takes place.

d. Policy actions, relating to potential interventions, aimed at the implementation of various policies.

The following are the stages of strategy formulation using Multipol:

1. Determine the policy for the development of cayenne chili which is input into the policy matrix against the criteria.

2. Determine actions/programs for developing cayenne chili commodities to realize predetermined policies that are input into the actions matrix against the criteria.

3. Determine the criteria/objectives for the development of cayenne chili in Ponorogo Regency.

4. The matrix for filling actions against the following criteria
Table 1. Matrix for filling actions against the following criteria

\begin{tabular}{|l|l|l|l|l|l|l|}
\hline & B6 & B5 & B4 & B3 & B2 & B1 \\
\hline A1 & & & & & & \\
\hline A2 & & & & & & \\
\hline A3 & & & & & & \\
\hline A4 & & & & & & \\
\hline A5 & & & & & & \\
\hline A6 & & & & & & \\
\hline
\end{tabular}

Based on the table above, the number of filling in the matrix is in the range of 0-20. In FGD, this score was scaled to 1 to 5 (scaling down) with 4 intervals $(1=4,2=8,3=12,4=16$, and $5=20)$.

5. The policy filling matrix against the following criteria:

Table 2. Policy filling matrix against the following criteria

\begin{tabular}{|l|l|l|l|l|l|l|l|}
\hline & Sum & B6 & B5 & B4 & B3 & B2 & B1 \\
\hline C1 & & & & & & & \\
\hline C2 & & & & & & & \\
\hline C3 & & & & & & & \\
\hline C4 & & & & & & & \\
\hline
\end{tabular}

Based on the table above, the total number of each policy is 100 . The same is true for filling in the weights from scenarios to criteria with a total weight of 100 for each scenario.

6. The scenario filling matrix against the criteria is as follows:

Table 3. Scenario filling matrix against the criteria is as follows

\begin{tabular}{|l|l|l|l|l|l|l|l|}
\hline & Sum & B6 & B5 & B4 & B3 & B2 & B1 \\
\hline DS & & & & & & & \\
\hline SS & & & & & & & \\
\hline
\end{tabular}
commodity based on the demand side emphasizes the economic level and the supply side.

7. The following is an evaluation based on actions and policies:

Table 4. Evaluation based on actions and policies

\begin{tabular}{|c|c|c|c|c|c|c|c|}
\hline \multirow{2}{*}{ Action } & \multicolumn{4}{|c|}{ Policy } & \multirow{2}{*}{$\begin{array}{c}\text { Means } \\
\text { value }\end{array}$} & \multirow{2}{*}{$\begin{array}{l}\text { Standart } \\
\text { Deviation } \\
\end{array}$} & \multirow{2}{*}{ Position } \\
\hline & $\mathrm{Cl}$ & $\mathrm{C}_{2}$ & $\mathrm{C} 3$ & $\mathrm{C} 4$ & & & \\
\hline $\mathrm{A} 1$ & & & & & & & \\
\hline A 2 & & & & & & & \\
\hline A3 & & & & & & & \\
\hline $\mathrm{A} 4$ & & & & & & & \\
\hline A5 & & & & & & & \\
\hline A6 & & & & & & & \\
\hline
\end{tabular}


Based on the table above, the results of Multipol analysis are presented based on the score for each policy and the average score, as well as the standard deviation obtained. In Multipol, the higher the position number, the better the performance of the action.

\section{RESULTS AND DISCUSSION}

The following are the actions, policies of the Ponorogo Regency Government and the results of the strategy analysis:

Table 5. Goal achievement criteria for chili development strategy cayenne

\begin{tabular}{|l|l|l|}
\hline \multicolumn{1}{|c|}{ Aim } & \multicolumn{1}{|c|}{ Criteria } & \multicolumn{1}{c|}{$\begin{array}{c}\text { Criteria } \\
\text { Description }\end{array}$} \\
\hline $\begin{array}{l}\text { Economic } \\
\text { dimension }\end{array}$ & Income & $\begin{array}{l}\text { Increased } \\
\text { revenue }\end{array}$ \\
\cline { 2 - 3 } & Competitiveness & $\begin{array}{l}\text { Increasing } \\
\text { competitiveness }\end{array}$ \\
\hline $\begin{array}{l}\text { Social } \\
\text { Dimension }\end{array}$ & Employment & Employment \\
\cline { 2 - 3 } & New business & $\begin{array}{l}\text { New business } \\
\text { growth }\end{array}$ \\
\hline $\begin{array}{l}\text { Environmental } \\
\text { protection }\end{array}$ & Pollution & $\begin{array}{l}\text { Reduction of } \\
\text { environmental } \\
\text { pollution }\end{array}$ \\
\hline Accessibility & Connective & $\begin{array}{l}\text { Infrastructure } \\
\text { network } \\
\text { upgrade }\end{array}$ \\
\hline
\end{tabular}

The scenarios used for the agribusiness development strategy for cayenne chili in Ponorogo Regency are Demand Side (DS) and Supply Side (SS). The following is the policy of the Ponorogo Regency Government related to horticulture development:

- Hatchery/Nursework Development

- Plant Protection Development

- Agricultural Agribusiness Development

- Yield Promotion Development

- Development of Food Crops and Organic Horticulture

The following are the actions in the strategy of developing cayenne chili agribusiness in Ponorogo Regency:

Table 6. Actions in cayenne chili development strategy

\begin{tabular}{|l|l|}
\hline \multicolumn{1}{|c|}{ Action } & \multicolumn{1}{|c|}{ Action description } \\
\hline irrigation network & $\begin{array}{l}\text { Improvement of irrigation } \\
\text { network }\end{array}$ \\
\hline Price fluctuation & Price stabilization \\
\hline $\begin{array}{l}\text { Agricultural } \\
\text { Extension }\end{array}$ & $\begin{array}{l}\text { Improved } \\
\text { extension }\end{array}$ \\
\hline $\begin{array}{l}\text { The suitability of } \\
\text { technology to the } \\
\text { needs of farmers }\end{array}$ & $\begin{array}{l}\text { Development of technology } \\
\text { suitability with farmers' needs }\end{array}$ \\
\hline Capital Institutions & $\begin{array}{l}\text { Capital institutional } \\
\text { development }\end{array}$ \\
\hline Market reach & Expansion of market reach \\
\hline
\end{tabular}

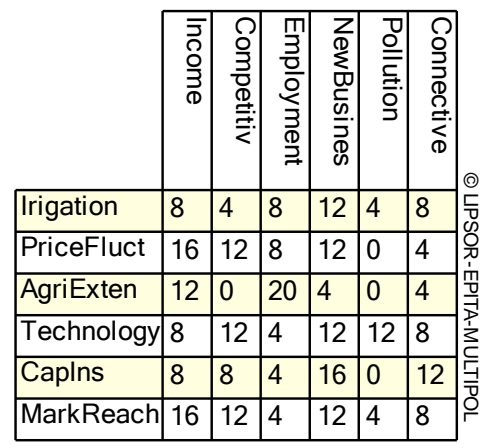

Figure 1. Action evaluation matrix related to criteria

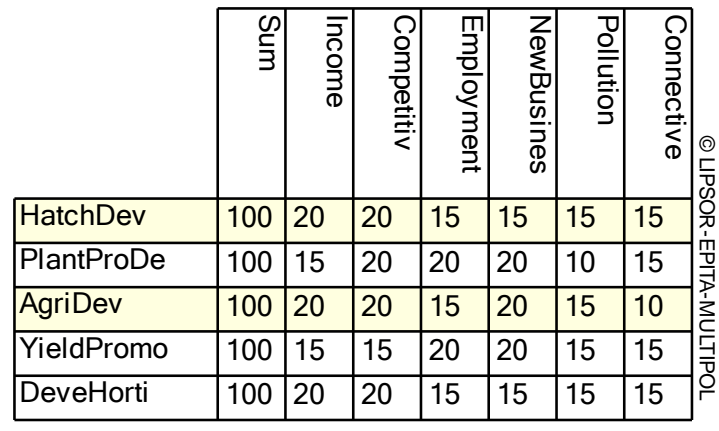

Figure 2. Policy evaluation matrix related to criteria 


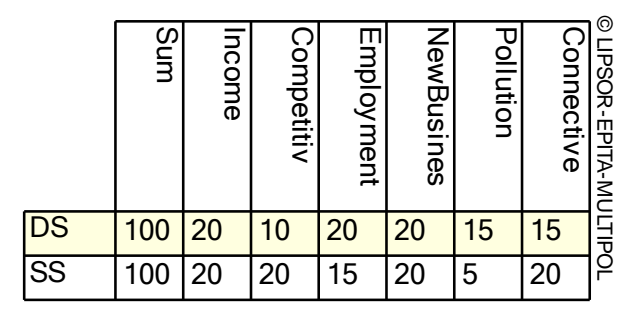

Figure 3. Scenario evaluation matrix related to criteria

\begin{tabular}{|c|c|c|c|c|c|c|c|c|}
\hline & 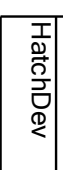 & 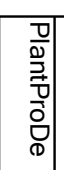 & 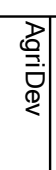 & $\begin{array}{l}\frac{2}{0} \\
\frac{0}{0} \\
\frac{0}{0} \\
\frac{3}{3}\end{array}$ & $\begin{array}{l}0 \\
0 \\
\mathbb{0} \\
\frac{1}{0} \\
=\end{array}$ & ఫ & & 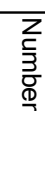 \\
\hline gation & 7.2 & \begin{tabular}{|l|}
7.6 \\
\end{tabular} & 7.4 & 7.6 & 7.2 & 7.4 & 0.2 & 2 \\
\hline riceFluct & \begin{tabular}{|l|}
9.2 \\
\end{tabular} & \begin{tabular}{|l|}
9.4 \\
\end{tabular} & \begin{tabular}{|l|}
9.6 \\
\end{tabular} & 8.8 & 9.2 & 9.2 & 0.3 & 4 \\
\hline riExten & 6.6 & 7.2 & 6.6 & 7.2 & 6.6 & 6.8 & 0.3 & 1 \\
\hline echnology & 9.4 & 9.2 & 9.6 & 9.2 & 9.4 & 9.4 & 0.2 & 5 \\
\hline aplns & 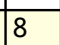 & 8.6 & 8.2 & 8.2 & 8 & 8.2 & 0.2 & 3 \\
\hline $\mathrm{kR}$ & 9.8 & 9.6 & 10 & 9.2 & 9.8 & 9.7 & & \\
\hline
\end{tabular}

Figure 4. The results of the analysis of evaluation and classification of actions against policies

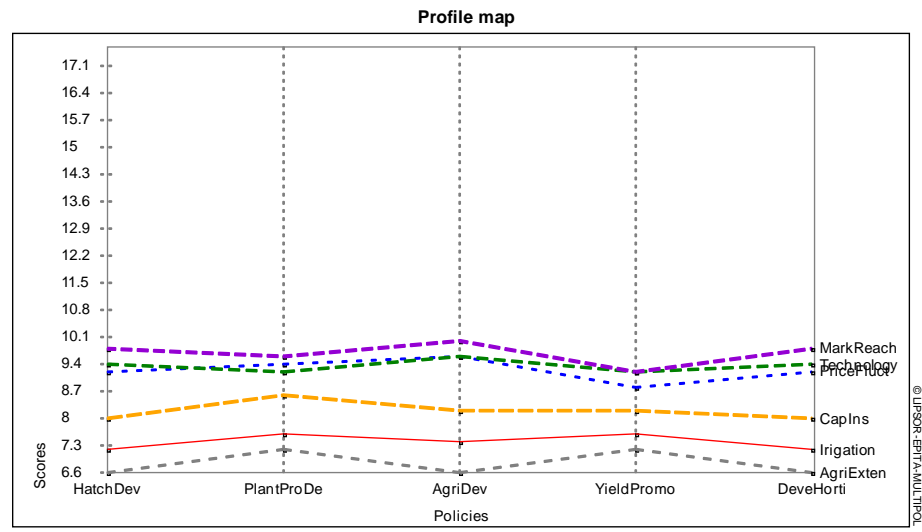

Figure 5. Profile map action against policy

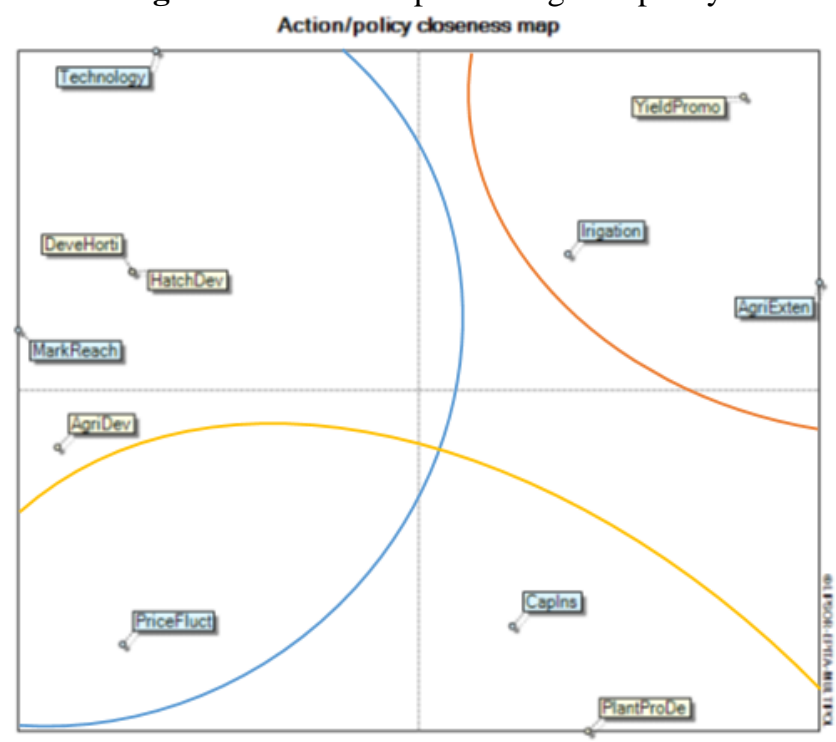

Figure 6. Closeness map action against policy 


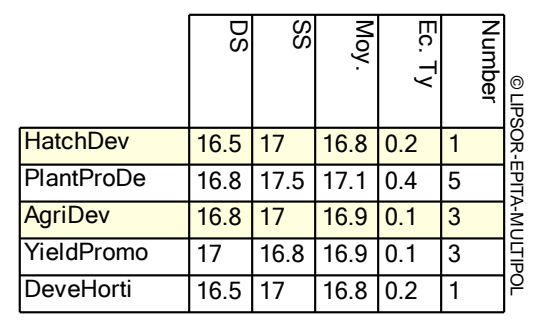

Figure 7. The results of the analysis of policy evaluation and classification of scenarios

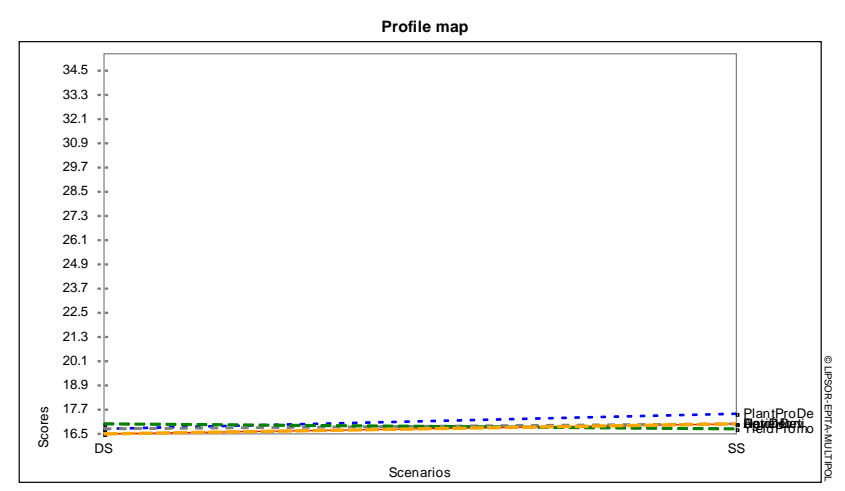

Figure 8. Profile map policy against scenario

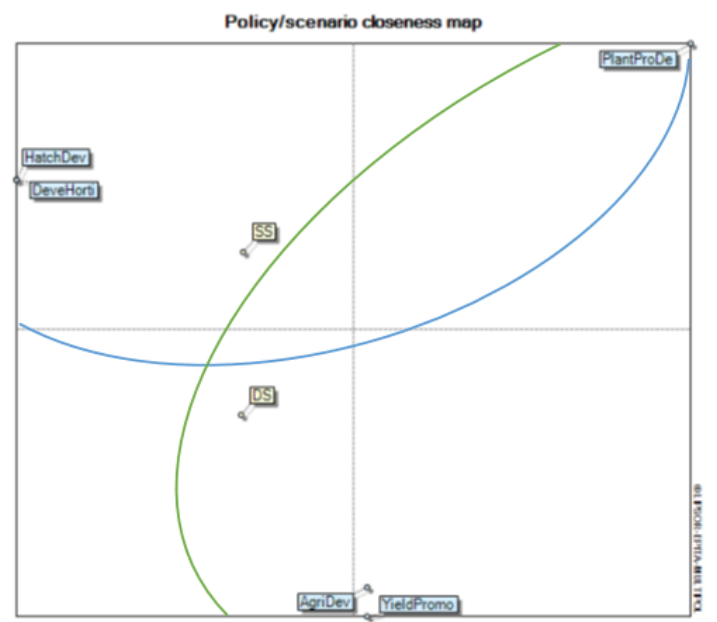

Figure 9. Closeness map policy to scenario

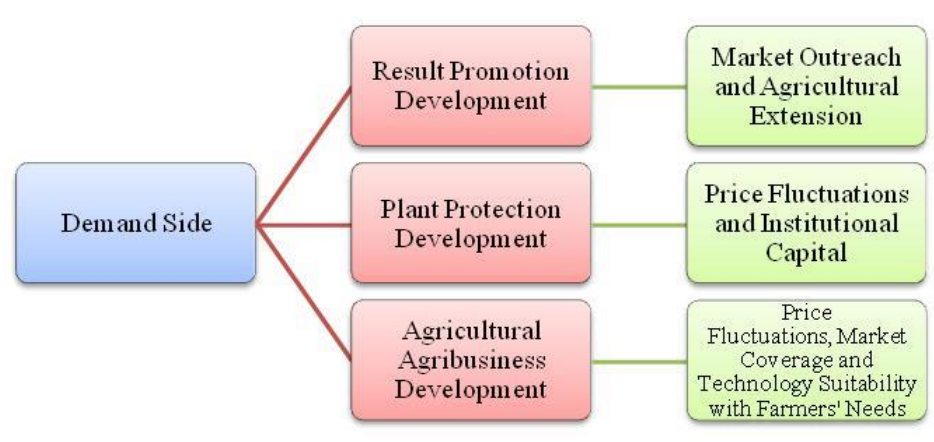




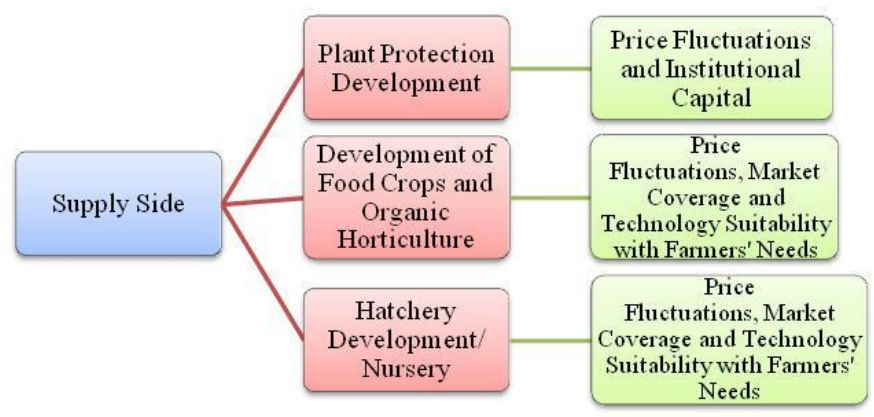

Figure 10. Policy path for the strategy of developing cayenne chili agribusiness in Ponorogo Regency

The following are the results of data analysis that has been carried out from the evaluation of the Ponorogo Regency Government policies related to the suggested scenario:

a) In the Demand side scenario, the farmers' demand/needs for the development strategy of cayenne chili agribusiness in Ponorogo Regency is the development of crop protection and agricultural agribusiness. The policy on the development of plant protection includes the role of agricultural extension workers to provide education to cayenne chili farmers about how to cultivate cayenne chili properly, how to deal with pests and diseases in cayenne chili plants and how to prevent them. In addition, farmers can also use technology to seek knowledge about plant protection in cayenne chili. As for the development of agricultural agribusiness, namely the role of farmers in increasing the production of cayenne chilito compete and expand market reach.

b) In the supply side scenario, the supply side/government program for the cayenne chili agribusiness development strategy in Ponorogo Regency is the development of plant protection. The role of the government to support the development of cayenne chili plant protection is to provide knowledge to farmers about the production of cayenne chili to obtain satisfactory results and provide knowledge on how to prevent and handle when cayenne chili plants are attacked by pests and diseases.

Policy path application of the Multi-Criteria Evaluation Model on developing cayenne chili agribusiness in Ponorogo Regency. The strategy for developing cayenne chili agribusiness in Ponorogo Regency is based on policies that have been structured as follows:

1. Demand Side (DS) are as follows:

a) The development of product promotion is 1) Expansion of market reach by increasing cayenne chili production; and 2) Improved of agricultural extension by providing knowledge to farmers about cultivation, care and how to overcome and prevent pests and diseases. b) The development of crop protection is by 1) Stabilize price fluctuations by involving the role of the government by providing transparency regarding prices, and 2) Development of capital institutions by providing easy access for farmers to obtain capital assistance such as fertilizers, medicines and infrastructure.

c) The development of agricultural agribusiness is by 1) Stabilize price fluctuations by involving the role of the government by providing transparency regarding prices, 2) Expansion of market reach by increasing cayenne chiliproduction by farmers, and 3) Technology suitability with farmers needs by using technology for the cultivation of cayenne chili from planting to the promotion of cayenne chili to consumers.

2. Supply Side(SS) are as follows:

a) The development of plant protection, namely 1) Stabilize price fluctuations involving the role of the government by distributing the time of cayenne chiliplanting in each region, 2) Development of capital institutions by providing assistance related to fertilizers, medicines and infrastructure.

b) The development of food crops and organic horticulture, namely 1) Stabilize price fluctuations involving the role of the government by distributing the time of cayenne chili planting in each region, 2) Expansion market reach by facilitating marketing access for farmers so that products reach consumers' easily, and 3) The suitability of technology with the needs of farmers by providing the right technological knowledge for cayenne chili cultivation starting from planting to promoting cayenne chili to consumers.

c) The development of hatcheries/nurseries, namely 1) Stabilize price fluctuations involving the role of the government by distributing the time of cayenne chili planting in each region, 2) Expansion market reach by facilitating marketing access for farmers so that products reach consumers' easily, 3) The suitability of technology with the needs of farmers by providing the right technological knowledge for cayenne chili cultivation starting from planting to promoting cayenne chili to consumers. 


\section{CONCLUSION}

The policies resulting from Multipol analysis for the strategy of developing cayenne chili in Ponorogo Regency are Demand side (DS) or farmers' needs, namely: 1) Product promotion development, 2) Agricultural protection development, and 3) Agricultural agribusiness development. Supply side (SS) or government programs are: 1) Development of plant protection, 2) Development of food crops and organic horticulture, and 3) Development of hatcheries/nurseries.

Based on the results of the analysis that has been carried out, the government should be more serious in efforts to develop cayenne chili agribusiness. The support that the government should give is starting from upstream to downstream through the policies that have been produced and providing assistance in the form of knowledge and capital.

\section{AUTHORS' CONTRIBUTIONS}

ARN, RI and M. Contributed to the design and implementation of the research, the analysis of the results, and the manuscript's writing.

\section{ACKNOWLEDGMENTS}

The researcher would like to thank the Department of Agriculture and Food of Ponorogo Regency and Agricultural Extension Center for the permission given to carry out the research and the staff who have helped during the research process.

\section{REFERENCES}

[1] Badan Pusat Statistik, Produk Domestik Bruto Triwulan 2016-2020, in: Jakarta: BPS Indonesia, 2020.

[2] Muksin, Hari R, Tanti K, and Titik I, Permasalahan Pokok Agribisnis Tembakau Na-Oogst di Jember, IOP Conf, 2018, Ser: Earth Environ. Sci. 207012012.pp.1-5.

[3] Nurdin, Teknologi dan Pengembangan Agribisnis Cabai di Kabupaten Boalerno Provinsi Gorontalo, Journal of Agricultural Research and Development, 30(2): 55-56, 2011,

[4] Muksin, Rizal, and Ridwan I, Analisis Status Berkelanjutan Produksi Tanaman Pasca Bencana di Kabupaten Sigi Provinsi Sulawesi Tengah, IOP Conf, 2021, Ser: Earth Environ. Sci. 672012031.pp.1-8

[5] Badan Pusat Statistik Ponorogo, Kabupaten Ponorogo dalam Angka, in: Ponorogo, BPS Kabupaten Ponorogo, 2020.

[6] Panagiotopoulou, M and Anastasia, S, Participatory Methodological Framework for Opening
Alternative Local Tourism Development Paths The Case of the StereaEllada Region. Eur J Futures Res, 4:1-15, 2014, https://eujournalfuturesresearch.springeropen.com/a rticles/10.1007/s40309-014-0044-7 